\title{
The Effect of Company Size on Company Profitability and Company Value: The Case of Manufacturing Companies
}

\author{
Submitted 05/01/19, 1st revision 20/02/19, 2nd revision 23/03/19, accepted 15/04/19 \\ Anasthasia Triwulan Budisaptorini ${ }^{1}$, Grahita Chandrarin ${ }^{2}$, Prihat Asih ${ }^{3}$
}

\begin{abstract}
:
Purpose: Economic conditions have created a tough competition between companies in the industry. The large companies, seek to obtain, acquire, develop, utilize, maintain and disclose strategic resources to the fullest. The paper aims to examine the effects of company size to company profitability and corporate value.

Design/Methodology/Approach: The article used random sampling analyzed by variable linearity assumption test. The population consists by manufacturing companies which are included in LQ 45 Index 2013-2015, during the period February 2013 until August 2015 for 6 consecutive years. There are as many as 25 companies in the sample.

Findings: The result shows that firm size has strong influence to the determination of profitability and value of manufacturing companies in Indonesia, while profitability has no effect to their value, neither with company size through profitability to company value. This proves that together the size of the company and profitability have no influence on the value of the company, which is caused by profitability because of no effect on the value of the company.

Practical Implications: The perception of investors on the level of corporate success is reflected through the value of the company. Increased corporate value due to high stock prices will make investors believe the prospects of the company in the future.

Originality/Value: Results must be used by top management because in a highly competitive environment companies must choose the cheapest way in executing investment plans trying to maximize the value of the company.
\end{abstract}

Keywords: Company size, profitability, corporate value.

JEL code: G21, G29.

Paper type. Research article.

${ }^{1}$ STIEKN Jaya Negara Malang, Jl. R. Tumenggung Suryo No.17, Bunulrejo, Blimbing, Kota Malang, Jawa Timur 65123, Indonesia, e-mail:

anasthasia.stiekn.jnm@gmail.com

${ }^{2}$ Universitas Merdeka Malang, Jl. Terusan Dieng No. 62-64 Klojen, Pisang Candi, Sukun, Kota Malang, Jawa Timur 65146, Indonesia.

${ }^{3}$ Universitas Merdeka Malang, Jl. Terusan Dieng No. 62-64 Klojen, Pisang Candi, Sukun, Kota Malang, Jawa Timur 65146, Indonesia. 


\section{Introduction}

The tight competition that emerges requires the company to further improve performance and innovate with its products to be better known by the public (Cheng $\&$ Tzeng, 2011). The company will consider the size in determining its debt policy (Handayani et al., 2009; Fakhimuddin, 2018). Company size is the size or the amount of assets owned by the company (Kurshev \& Strebulaev, 2007). Companies that are considered big in size, seek to obtain, acquire, develop, utilize, maintain and disclose strategic resources to the fullest. The size of a company is shown by its total assets, the amount of sales, the average total sales, the average total assets (Weston 1993, pp. 57-58).

On the other hand, profitability is the company's ability to generate profit in the future and is an indicator of the company's operational success. The company's value is the present value of free cash flow in the future at an appropriate discount rate weighted by the average cost of capital (Brigham and Ehrhardt, 2005, p. 518). Company's value is a value that can be used to measure how much the importance of a company is viewed from the perspective of some parties such as investors who associate the value of a company from the stock price of the company (Hermuningsih, 2013). Maximizing the value of the firm is the same as maximizing stock prices and that is what the company owner wants, because high company values indicate high shareholder wealth (Brigham, 2006; Gultom et al., 2013; Susilo, 2018; Rizki et al., 2019; Suwanti et al., 2018). The paper aims to examine the effects of company size to company profitability and corporate value.

\section{Literature Review}

The size of the firm describes the size of a company indicated by total assets, total sales, average total sales and average total assets (Sujianto, 2001). The size of the firm is proxyed by total assets. Total assets of a company have a strategic influence on the company's competition, so that the value of the company proxied by total assets can be stated as follows.

\section{Company size $=$ Total assets}

Profitability is the company's ability to earn profits, in relation to sales and total assets and own capital (Sartono, 2010). Profitability is proxied with Return on Assets (ROA). ROA is a ratio that measures the rate of return on an asset, so the value of the company proxied by Returnet on Assets can be stated as follows (Brigham and Houston, 2013).

\section{Profitability $=$ Net income after tax/total assets}

The value of the company represents the present value of free cash flow in the future at a discount rate in accordance with the weighted average cost of capital. Free cash 
flow is a cash flow available to investors (creditor and owner) after taking into account all expenses for the company's operations and expenditures for investment and net current assets (Brigham \& Ehrhardt, 2005). Company value is proxied with Price to Book Value (PBV). PBV is the result of comparison between the stock price and the value of stock book, so the value of the company proxies with Price to Book Value can be stated as follows (Brigham and Ehrharddt, 2005 ).

Corporate Value $(N P)=$ Market price per share /book value per share

\section{Conceptual Framework and Hypotheses}

The conceptual framework developed in this study can be presented as follows.

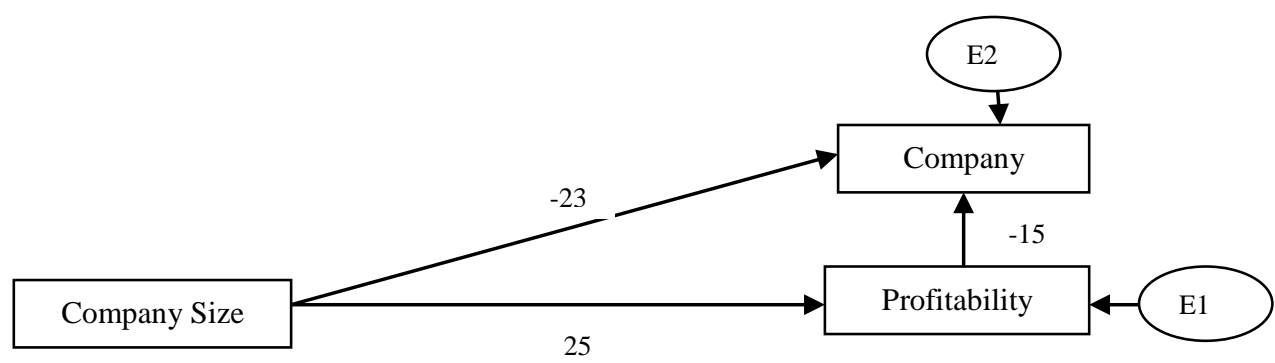

Based on the abovementioned framework, the hypotheses proposed in this study are:

H1: There are positive and significant effects of company size on corporate value.

H2: There are positive and significant effects of company size on profitability.

H3: There are positive and significant effects of profitability on corporate value.

H4: There are positive and significant effects of company size on corporate value through profitability.

\section{Methodology}

The population in this research is manufacturing companies which are included in LQ 45 Index 2013-2015, during the period February 2013 until August 2015 for 6 consecutive years. There are as many as 25 companies namely: Astra Agro Lestari (AALI), Adaro Energy (ADRO), AKR Corporindo (AKRA), Astra International (ASII), Alam Sutera Realty (ASRI), Bank Central Asia (BBCA), Bank Negara Indonesia (BBNI), Bank Rakyat Indonesia (BBRI), Bank Mandiri (BMRI), Global Mediacom (BMTR), Bumi Serpong Damai (BSDE), Charoen Pokphan Indonesia (CPIN), XL Axiata (EXCL), Gudang Garam (GGRM), Indofood CBP Sukses Makmur,Tbk ( ICBP), Indofood Sukses Makmur (INDF), Indocement Tunggal Prakasa ( INTP), Indo Tambangraya Megah (ITMG), Jasa Marga (Persero) (JSMR), Kalbe Farma ( KLBF), Lippo Karawaci ( LPKR), PP London Sumatera ( LSIP), Media Nusantara Citra (MNCN), Perusahaan Gas Negara (PGAS), Tambang 
Batubara Bukit Asam (PTBA), Semen Indonesia ( SMGR), Telekomunikasi Indonesia ( TLKM), United Tractors (UNTR) and Unilever Indonesia (UNVR).

Data collection was performed by means of document data in financial statements available from: Indonesian Capital Market directory (ICMD) during 2013 to 2015, and from IDX during 2014 to 2016.

\section{Results and Analysis}

The statistical calculation as shown in Table 1 reveal the result of the linearity assumption test for the dependent variable (Corporate Value and Profitability).

Table 1. Assessment of variable linearity assumption of company value

\begin{tabular}{|c|c|c|c|}
\hline Equation & $R$ Square & Fcount & Signification \\
\hline Linear & 0.041 & 3.014 & 0.087 \\
\hline
\end{tabular}

Table 1 is a linearity assumption test for the dependent variable of company value with influenced variable profitability. Considering the significant linear model ( ignificance value $=0.087$ ), it is concluded that the relationship between the variable company value and profitability is linear (not significant at alpha $=5 \%$ level but significant at alpha $=10 \%$ level, statistic being $=0.087)$.

Table 2. Assessment of variable linearity assumption of company value

\begin{tabular}{|c|c|c|c|}
\hline Equation & $R$ Square & Fcount & Signification \\
\hline Linear & 0.072 & 5.460 & 0.022 \\
\hline
\end{tabular}

Table 2 is a linearity assumption test for the dependent variable of company value with influenced variable company size. Considering the significant linear model ( ignificance value $=0.022$ ), it is concluded that the relationship between the variable company value and company size is linear (significant at alpha $=5 \%$ level, statistic being $=0.022$ ).

Table 3. Testing the linearity assumption of variables emotions

\begin{tabular}{|c|c|c|c|}
\hline Equation & $R$ Square & Fcount & Signification \\
\hline Liniear & 0.061 & 4.574 & 0.036 \\
\hline
\end{tabular}

Table 3 is a linearity assumption test for dependent variable of profitability with influenced variable company size. Considering the significant linear model ( significance value $=0.036$ ), it is concluded that the relationship between the variable profitability and company size is linear (significant at alpha $=5 \%$ level, statistic being $=0.036$ ). Moreover, in path analysis is also used direct effect, indirect effect and total effect. These three types of influences are often interpretable whereas two other types of influence exist, but they are difficult to be interpreted. 
Table 4: Estimation of path coefficients

\begin{tabular}{|c|c|c|c|c|c|c|}
\hline & & & Estimate & S.E. & C.R. & Sig. \\
\hline $\mathrm{Y}$ & $<---$ & $\mathrm{X}$ & 0.000 & 0.000 & 2.154 & 0.031 \\
\hline $\mathrm{Z}$ & $<---$ & $\mathrm{Y}$ & -0.065 & 0.052 & -1.246 & 0.213 \\
\hline $\mathrm{Z}$ & $<---$ & $\mathrm{X}$ & 0.000 & 0.000 & -1.996 & 0.046 \\
\hline
\end{tabular}

Table 5: Estimation of standardized path coefficients

\begin{tabular}{|c|c|c|c|}
\hline & & & Estimate \\
\hline $\mathbf{Z}$ & $<---$ & $\mathrm{X}$ & 0.248 \\
\hline $\mathbf{Y}$ & $<---$ & $\mathrm{Z}$ & -0.145 \\
\hline $\mathbf{Y}$ & $<---$ & $\mathrm{X}$ & -0.233 \\
\hline
\end{tabular}

Tables 4 and 5 are used to show the results of the path coefficient test. From Table 4 it is known that the significance value for the variable Company Size (X) is 0.031 (smaller than alpha $=0.05$ ) which means that Company Size $(X)$ affects profitability (Y). The value of significance for the variable Profitability (Y) is 0.213 (greater than alpha $=0.05)$ which means profitability $(Y)$ has no effect on Corporate Value $(Z)$. The value of significance for the variable Company Size $(X)$ is 0.046 (smaller than alpha $=0.05)$ which means Company Size $(X)$ has an effect on Corporate Value $(Z)$. Based on statistical testing, the value of direct effect can be obtained from Table 5 as follows:

1. The magnitude of the direct influence of firm size on firm value is -0.233 (Table 5). This effect is significant. Thus, hypothesis 1 is accepted.

2. The magnitude of influence of company size to profitability is 0.248 . The effect is significant. Thus, hypothesis 2 is accepted.

3. The magnitude of influence from profitability to corporate value is -0.145 , but the influence is not significant. Thus, hypothesis 3 is rejected.

Moreover, the amount of indirect effect of company size on corporate value through profitability is $-0.036(0.248 *-0.145)$. However, the indirect effect is insignificant because the influence of company value is insignificant and does not need to proceed to Sobel test (indirect effect test). This is because on the Sobel test, it is required the effect of company size to corporate value through profitability to be significant. Thus, hypothesis 4 is rejected. Finally, it is a need to explain the value of coefficient of determination as the value showing the extent to which the generalizability of independent variables to dependent ones is.

$\mathrm{R}_{\mathrm{m}}^{2}=1-(1-0.061)(1-0.092)$

$\mathrm{R}_{\mathrm{m}}^{2}=0.147$

The generalizability of data that can be explained by the model is $14.70 \%$ or in other words the information contained in the $14.70 \%$ data can be explained by the model while $85.30 \%$ is explained by other variables ommitted in the model. 


\section{Conclusions}

The results of this study show that the size of the company has a strong influence on the determination of the value of manufacturing companies in Indonesia. This proves that the larger the size of the company, the greater the value of the company. The size of the company has a strong influence on the determination of the value of profitability of manufacturing companies in Indonesia. This proves that the larger the size of the company, the greater the profitability of the company concerned. Profitability has no effect on the value of manufacturing companies in Indonesia. Moreover, the statistical analysis shows that the company size through profitability on corporate value has no influence.

\section{References:}

Brigham, E.F. 2006. Fundamental of Financial Management, 8th Ed. Cengange Learning, USA.

Brigham, E.F., Ehrhardt, M. 2005. Financial Management Theory and Practice, Eleventh Edition. South Western Cengage Learning, Ohio.

Brigham, E.F. and Houston, J.F. 2013. Fundamental of Financial Management, 8th Ed. Cengage Learning,USA.

Cheng, M.C. \& Tzeng, Z.C. 2011. The Effect of Leverage on Firm Value and How the Firm Financial Quality Influence on this Effect. World Journal of Management, 3(2), 30.

Fakhimuddin, M. 2018. Reconsidering Accounting Information Systems: Effective Formulations for Company's Internal Control. Arthatama Journal of Business Management and Accounting, 2(1).

Gultom, R.A. \& Wijaya, S.W. 2013. Analysis of Factors Affecting Company Values in Pharmaceutical Companies on the Indonesia Stock Exchange. Mikrosil Economic Journal, 3(1), 51-60.

Handayani, R.S., Agustono, D. \& Rachadi, D. 2009. Effect of Company Size on Profit Management. Journal of Business and Accounting, 11(1), 33-56.

Hermuningsih, S. (n.d.). Influence of Profitability, Growth Opportunity, Capital Structure Against Corporate Values in Public Companies in Indonesia.

Kurshev, A. \& Strebulaev, I. 2007. Firm Size and Capital Structure. Retrieved from http://ssrn.com/abstract $=686412$

Rizki, Moch., Parashakti, D.R. \& Saragih, L. 2019. The Effect of Transformational Leadership and Organizational Culture Towards Employees' Innovative Behaviour and Performance. International Journal of Economics \& Business Administration, 7(1), 227-239.

Susilo, D.E. 2018. The Effects of Corporate Social Responsibility on Corporate Value. Arthatama Journal of Business Management and Accounting, 2(1).

Suwanti, S., Udin, U. \& Widodo, W. 2018. Person-Organization Fit, Person-Job Fit, and Innovative Work Behavior: The Role of Organizational Citizenship Behavior. International Journal of Economics \& Business Administration, 6(3), 146-159.

Weston, J.F. and Brigham, B. 1993. Essential of Managerial Finance, 10th Ed. The Dryden Press, New York. 